\title{
Disease concurrence in diabetes mellitus: a study of concurrent morbidity over 12 months using diabetes mellitus as an example
}

\author{
D M Fleming, D L Crombie, $\mathrm{K}$ W Cross
}

\begin{abstract}
Study objective-The aim was to examine disease concurrence, using diabetes mellitus as an illustrative example.

Design-The study involved a general practice morbidity survey, conducted over 12 months in 1981-82. All patients who consulted their general practitioners with a diagnosis of diabetes mellitus (type 1 or type 2) were identified and the number of these who consulted with additional morbidities were counted for each rubric of the Royal College of General Practitioners' modification of the International Classification of Disease. These observed numbers were then compared with expected numbers calculated from the total non-diabetic population after standardisation by age. Standardised person consulting ratios (SPCR) were derived and the $99 \%$ confidence intervals $(\mathrm{CI})$ surrounding these values calculated.
\end{abstract}

Setting-This was a national survey involving the whole of England and Wales.

Patients-The study involved 280000 patients from selected general practices, of whom 953 males and 1035 females consulted their general practitioners with diabetes.

Measurements and main results-In an examination of 80 disease rubrics in the diabetic population in which there were at least 20 observed or expected cases, there were 34 among males and 28 among females in which there were increased values of the SPCR, and none in which the SPCR was decreased. SPCRs were high for infections generally (bacterial, fungal, and viral) and particularly so for cardiovascular disorders and for hypothyroidism in males. Though SPCRs for upper respiratory infections were increased, those for asthma and hay fever were not. SPCRs for neoplasms as a group were not raised.

Conclusion-By confirming other work and widely held clinical opinion, this study has shown the potential of this data base for the examination of disease concurrence.

The study reported here is concerned with diseases occurring together within a 12 month period and therefore we have described this as a study of disease concurrence. In this exercise, there will be some people newly diagnosed with the index disease during the 12 months and others who have had the condition for several years. Other words used in epidemiological studies of this type include: "association", which does not imply any temporal quality; "coincidence", implying incidence at the same time; and "coexistence", which implies an association at a single point in time.

Studies of any form of association are helpful towards: (1) identifying common aetiological factors; (2) providing an epidemiological perspective to confirm (or otherwise) clinical impressions; (3) identifying risk factors for preventive medical care; and (4) measuring commercial risk for employment and insurance, etc. These studies usually involve intensive investigation of a particular group of patients identified primarily by the morbidity but secondarily by such factors as attendance at a specialist clinic. It can be very difficult to obtain a representative sample of persons with a specific disease.

In the third national (England and Wales) morbidity study, based on general practice, doctors recorded in a diagnostic index ${ }^{1}$ the morbidity considered at every consultation during a 12 month period (1981-82). Recorded information included a coded patient identifier, the relevant morbid problem(s), and the episode type, whereby new episodes of illness are distinguished from recurrences. The patient identifier facilitated linkage between different morbidities.

The study population, though not randomly selected, was representative of the national population by age and sex. ${ }^{2}$ The practices participating may not have been representative of practices throughout the country and therefore are potentially biased in the extent to which illnesses are identified. For some illnesses (eg, mental illness), the potential must be recognised in the interpretation of the data; for others, where diagnostic criteria are firmer or where consensus exists, it is less relevant.

In this study, we illustrate the use of national morbidity study data by examining disease concurrence with diabetes. The extensive knowledge available about the prevalence of diabetes and its associations with other diseases provide an opportunity to assess the potential of the data base. Both type 1 and type 2 diabetes mellitus are associated with increased mortality. ${ }^{3}$ In patients developing diabetes beyond the age of $40,70 \%$ die from cardiovascular disease, the risk for the diabetic being two or three times that for non-diabetics. Renal failure is an important cause of death, especially in young diabetics, and some die from diabetic ketoacidosis.

\section{Methods}

Approximately 330000 persons were included in 
the third general practice morbidity study. Of these, 280000 were present in the study for the entire 12 month period and they constituted the study population. There were 1988 persons ( 953 male and 1035 female) who consulted their general practitioners with diabetes mellitus (index cases); ie, a person consulting rate of 7.5 per 1000 at risk. Counts were made among them of persons with concurrent morbidity in each of the other rubrics of the disease classification (Royal College of General Practitioners' modification of the International Classification of Disease). Expected numbers of cases for each rubric were calculated from the age composition of index cases (10 year age bands) and the age specific person consulting rates of each condition in the remaining study population (ie, all non-diabetics). The ratio of observed to expected (indexed to 100) provided the standardised person consulting ratio (SPCR). For each standardised person consulting ratio, the 99\% confidence interval (CI) was calculated assuming an underlying Poisson distribution of observed values. We chose the $99 \%$ level because of the large number of comparisons made in this study.

By using only the data concerning persons registered for the entire year, there was a theoretical danger that there could be a bias involving a loss of index cases due to withdrawal from the practice, especially because of death. As a check therefore, withdrawals among the index cases were counted ( 75 male and 78 female) and shown to be similar to the expected numbers calculated from total study withdrawals and the age and sex composition of index cases ( 74 and 79 respectively).

\section{Results}

Table I gives the $99 \%$ CI for the standardised person consulting ratio for diseases aggregated by Chapter of the International Classification of Disease. No data are presented for Chapter IIIEndocrine disorders-because it includes diabetes, and the chapters concerned with complications of pregnancy, congenital malformations, and perinatal conditions have been excluded because of the very small numbers involved. High values of the standardised person consulting ratio for index cases were found in both sexes and in all chapters, with the exception of neoplasms (both sexes) and blood disorders (females). Ratios for the sexes were broadly similar, but there was considerable variation between chapters.

In table II data are presented for the 80 (out of a total of 330) morbidity rubrics in which there were 20 or more observed or expected cases. The data given include the number of cases of each sex, the standardised person consulting ratios, and the confidence intervals. No diagnosis by site within Chapter II-Neoplasms - met the above criterion.

The tables are self explanatory and comment is restricted to diseases of special interest; mention is made of some involving less than 20 cases. Using the data for Chapter I as an example, the confidence intervals for males do not include 100 (excepting dermatophytosis) and therefore the standardised person consulting ratios are significant at the $1 \%$ level. Among females, the consulting ratios for two conditions were significant at this level. In the case of nonurogenital monilia infection, the consulting ratio was significantly increased at this level for males $(n=8, S P C R=485, C I=156-1127)$ but not for females $(n=8, S P C R=250, C I=80-581)$.

In Chapter V-Mental disorders-there is an interesting contrast between the results for anxiety state (SPCR 91) and those for depressive disorder (SPCRs 231 and 169). There were eight males with psychogenic disorders of sexual function, SPCR 471 (CI 151-1094). For Chapter VII-Diseases of the circulatory systemstandardised person consulting ratios are uniformly high (excluding varicose veins). For Respiratory diseases (Chapter VIII), high consulting ratios only occurred for upper respiratory tract infections (febrile and male nonfebrile) and for acute bronchitis.

In Chapter XII-Skin disorders-consulting ratios were especially high for infective conditions and for chronic ulcer of skin. For Musculoskeletal disorders (Chapter XIII), consulting ratios were in general not significantly high at the $1{ }^{\circ}{ }_{0}$ level, the exception being non-specific limb pains for both males and females and non-specific arthritis for females. In Chapter XVII-Accidents, injuries etc-it is noteworthy that the consulting ratios were significantly increased for the adverse effects of medication.

\section{Discussion}

The examination of disease concurrence requires unique patient identification for linkage and entry of every relevant event referable to a substantial population. The general practice based morbidity studies for England and Wales are almost unique in achieving this comprehensive ideal over the total range of morbidity and most especially in a nationally representative population.
Table I Standardised person consulting ratios (SPCR) by chapter of International

Classification of Disease

\begin{tabular}{|c|c|c|c|c|c|c|c|}
\hline \multirow[b]{2}{*}{ Chapter } & & \multicolumn{3}{|l|}{ Males } & \multicolumn{3}{|c|}{ Females } \\
\hline & & Cases & $S P C R$ & $(C I)$ & Cases & $S P C R$ & $(C I)$ \\
\hline I & Infections & 118 & 222 & $(173-281)$ & 146 & 201 & $(161-248)$ \\
\hline II & Neoplasms & 21 & 112 & $(59-192)$ & 22 & 100 & $(54-170)$ \\
\hline IV & Blood disorders & 14 & 232 & $(103-445)$ & 24 & 146 & $(81-242)$ \\
\hline $\mathrm{V}$ & Mental disorders & 91 & 140 & $(105-183)$ & 179 & 129 & $(105-156)$ \\
\hline VI & Disorders of nervous system & 167 & 135 & $(110-165)$ & 203 & 137 & $(113-164)$ \\
\hline VII & Cardiovascular disease & 309 & 188 & $(162-218)$ & 352 & 179 & $(155-205)$ \\
\hline VIII & Respiratory disease & 271 & 136 & $(115-158)$ & 315 & 140 & $(120-161)$ \\
\hline IX & Gastrointestinal disease & 125 & 149 & $(117-187)$ & 139 & 145 & $(115-180)$ \\
\hline $\mathrm{X}$ & Genitourinary disease & 72 & 197 & $(143-266)$ & 166 & 158 & $(128-192)$ \\
\hline XII & Skin disease & 187 & 217 & $(178-261)$ & 203 & 182 & $(151-217)$ \\
\hline XIII & Musculoskeletal disease & 217 & 138 & $(115-164)$ & 299 & 131 & $(112-152)$ \\
\hline $\mathrm{XVI}$ & Symptoms, signs, etc & 211 & 161 & $(134-192)$ & 295 & 153 & $(131-177)$ \\
\hline XVII & Accidents, etc & 129 & 145 & $(115-182)$ & 176 & 146 & $(119-176)$ \\
\hline
\end{tabular}


Table II Standardised person consulting ratios (SPCR) for selected diagnoses

\begin{tabular}{|c|c|c|c|c|c|c|}
\hline & \multicolumn{3}{|l|}{ Males } & \multicolumn{3}{|c|}{ Females } \\
\hline & Cases & $S P C R$ & (CI) & Cases & $S P C R$ & $(C I)$ \\
\hline $\begin{array}{l}\text { CHAPTER I Infections } \\
\text { Intestinal inf disease }\end{array}$ & 33 & 181 & $(110-279)$ & & & \\
\hline $\begin{array}{l}\text { Herpes zoster } \\
\text { Hease }\end{array}$ & 14 & 261 & $(116-500)$ & 10 & 129 & $\begin{array}{l}(86-211) \\
(48-275)\end{array}$ \\
\hline Viral inf, not specified & 24 & 317 & $(175-525)$ & 24 & 260 & $(144-431)$ \\
\hline Dermatophytosis & 13 & 170 & $(73-334)$ & 12 & 219 & $(90-441)$ \\
\hline Monilia, urogenital & 10 & 751 & $(279-1607)$ & 48 & 517 & $(345-741)$ \\
\hline CHAPTER III Endocrine and metabolic disorder & & & & & & \\
\hline $\begin{array}{l}\text { Hypothyroidism } \\
\text { Obesity }\end{array}$ & $\begin{array}{r}9 \\
24\end{array}$ & $\begin{array}{l}660 \\
387\end{array}$ & $\begin{array}{l}(230-1467) \\
(214-640)\end{array}$ & $\begin{array}{l}22 \\
69\end{array}$ & $\begin{array}{l}188 \\
372\end{array}$ & $\begin{array}{l}(101-319) \\
(266-503)\end{array}$ \\
\hline CHAPTER IV Diseases of the blood and blood fo & orming orga & & & & & \\
\hline Iron deficiency anaemia & 9 & 312 & $(109-694)$ & 19 & 165 & $(84-289)$ \\
\hline $\begin{array}{l}\text { CHAPTER V Mental disorders } \\
\text { Anxiety state }\end{array}$ & & & & & & \\
\hline $\begin{array}{l}\text { Anxiety state } \\
\text { Denrescive disorder }\end{array}$ & 17 & 91 & $(44-165)$ & $\begin{array}{l}41 \\
82\end{array}$ & $\begin{array}{r}91 \\
169\end{array}$ & $\begin{aligned}(58-134) \\
(125-223)\end{aligned}$ \\
\hline $\begin{array}{l}\text { Depressive disorder } \\
\text { Insomnia and sleep disorders }\end{array}$ & $\begin{array}{r}41 \\
9\end{array}$ & $\begin{array}{l}231 \\
116\end{array}$ & $\begin{array}{r}(149-341) \\
(40-258)\end{array}$ & $\begin{array}{l}82 \\
20\end{array}$ & $\begin{array}{l}169 \\
121\end{array}$ & $\begin{array}{r}(125-223) \\
(62-209)\end{array}$ \\
\hline $\begin{array}{l}\text { Insomnia and sleep disorders } \\
\text { Transient situational disorders }\end{array}$ & 13 & 201 & $(86-394)$ & 28 & 144 & $\begin{array}{l}(62-209) \\
(83-230)\end{array}$ \\
\hline CHAPTER VI Discorders of the nervous system a & and sense or & gans & & & & \\
\hline Dis of nervous system NEC ${ }^{\text {a }}$ & 17 & 306 & $(149-555)$ & 16 & 188 & $(89-347)$ \\
\hline Cataracts & 12 & 305 & $(125-613)$ & 15 & 191 & $(88-358)$ \\
\hline Conjunctivitis & 18 & 117 & $(58-209)$ & 29 & 118 & $(69-187)$ \\
\hline Other diseases of eye & 16 & 195 & $(92-359)$ & 21 & 202 & $(106-345)$ \\
\hline Otitis externa & 11 & 98 & $(38-203)$ & 13 & 129 & $(56-254)$ \\
\hline Wax in ear & 40 & 105 & $(67-156)$ & 38 & 131 & $(83-196)$ \\
\hline CHAPTER VII Diseases of the circulatory systen & & & & & & \\
\hline & & $\begin{array}{l}264 \\
182\end{array}$ & $\begin{array}{l}(157-416) \\
(114-276)\end{array}$ & $\begin{array}{l}17 \\
36\end{array}$ & $\begin{array}{l}279 \\
252\end{array}$ & $\begin{array}{l}(135-505) \\
(157-382)\end{array}$ \\
\hline $\begin{array}{l}\text { Angina } \\
\text { Other chronic isch heart disease }\end{array}$ & $\begin{array}{l}36 \\
26\end{array}$ & $\begin{array}{l}182 \\
174\end{array}$ & $\begin{array}{r}(114-276) \\
(98-282)\end{array}$ & $\begin{array}{l}36 \\
30\end{array}$ & 260 & $\begin{array}{l}(157-382) \\
(154-409)\end{array}$ \\
\hline $\begin{array}{l}\text { Other chronic isch heart disease } \\
\text { Congestive cardiac failure }\end{array}$ & 26 & 189 & $\begin{array}{l}(98-282) \\
(107-308)\end{array}$ & $\begin{array}{l}30 \\
52\end{array}$ & $\begin{array}{l}260 \\
260\end{array}$ & $(177-368)$ \\
\hline & 14 & 231 & $(103-442)$ & 10 & 210 & $(78-450)$ \\
\hline Uncomplicated hypertension & 160 & 226 & $(183-277)$ & 191 & 197 & $(162-236)$ \\
\hline Other cerebrovasc disorders & 20 & 215 & $(111-373)$ & 19 & 198 & $(100-348)$ \\
\hline Peripheral vasc disorders & 25 & 352 & $(197-578)$ & 13 & 250 & $(107-490)$ \\
\hline Varicose veins & 18 & 169 & $(84-301)$ & 22 & 105 & $(56-178)$ \\
\hline CHAPTER VIII Diseases of the respiratory syste & & & & & & \\
\hline $\begin{array}{l}\text { URTI non-febrile } \\
\text { URTI febrile }\end{array}$ & $\begin{array}{l}60 \\
44\end{array}$ & $\begin{array}{l}144 \\
203\end{array}$ & $\begin{array}{l}(101-199) \\
(133-295)\end{array}$ & $\begin{array}{c}101 \\
33\end{array}$ & $\begin{array}{l}167 \\
137\end{array}$ & $\begin{array}{r}(127-214) \\
(83-211)\end{array}$ \\
\hline $\begin{array}{l}\text { Acute sinusitis } \\
\text { A }\end{array}$ & 11 & 135 & $(53-280)$ & 20 & 139 & $(72-242)$ \\
\hline $\begin{array}{l}\text { Tonsillitis } \\
\text { Totis }\end{array}$ & 13 & 133 & $(57-261)$ & 17 & 117 & $(57-212)$ \\
\hline Tracheitis & 12 & 121 & $(50-243)$ & 17 & 98 & $(48-178)$ \\
\hline Acute bronchitis & 103 & 148 & & 122 & 163 & $(128-205)$ \\
\hline Catarrh & 17 & 122 & $(59-220)$ & 15 & 87 & $(40-163)$ \\
\hline Hay fever & 12 & 139 & $(57-279)$ & 16 & 161 & $(76-296)$ \\
\hline Influenza & 22 & 151 & $(81-2$ & 19 & 133 & $(67-234)$ \\
\hline Chronic bronchitis & 24 & 117 & $(65-194)$ & 10 & 111 & $(41-238)$ \\
\hline Asthma & 20 & 129 & $(67-223)$ & 21 & 129 & $(68-220)$ \\
\hline $\begin{array}{l}\text { CHAPTER IX Diseases of the digestive system } \\
\text { Diseases of teeth, etc }\end{array}$ & & & & & & \\
\hline $\begin{array}{l}\text { Diseases of teeth, etc } \\
\text { Diseases of the mouth, etc }\end{array}$ & $\begin{array}{r}11 \\
9\end{array}$ & $\begin{array}{l}215 \\
166\end{array}$ & $\begin{array}{l}(84-444) \\
(58-370)\end{array}$ & $\begin{array}{l}14 \\
14\end{array}$ & $\begin{array}{l}211 \\
146\end{array}$ & $\begin{array}{l}(94-405) \\
(65-280)\end{array}$ \\
\hline Disorders of gastric function & 22 & 124 & $(67-211)$ & 29 & 156 & $(92-248)$ \\
\hline Irritable bowel syndrome & 11 & 143 & $(56-295)$ & 20 & 138 & $(72-240)$ \\
\hline Constipation & 29 & 284 & $(167-451)$ & 27 & 183 & $(105-295)$ \\
\hline CHAPTER X Diseases of the genitourinary systen & & & & & & \\
\hline $\begin{array}{l}\text { Urinary tract infection } \\
\text { Haematuria NEC }\end{array}$ & $\begin{array}{l}30 \\
12\end{array}$ & $\begin{array}{l}244 \\
350\end{array}$ & $\begin{array}{l}(144-383) \\
(144-705)\end{array}$ & $\begin{array}{r}68 \\
9\end{array}$ & $\begin{array}{l}173 \\
574\end{array}$ & $\begin{array}{l}(124-234) \\
(200-1275)\end{array}$ \\
\hline $\begin{array}{l}\text { Haematuria NEC } \\
\text { CHAPTER XII Diseases of the skin }\end{array}$ & & & $(144-705)$ & 9 & 574 & $(200-1275)$ \\
\hline Carbuncle and furuncle & 14 & 355 & $(158-680)$ & 11 & 330 & $(130-684)$ \\
\hline $\begin{array}{l}\text { Cellulitis and abscess of digits } \\
\text { Other cellulitis }\end{array}$ & 27 & 566 & $(325-912)$ & 29 & 414 & $(243-657)$ \\
\hline $\begin{array}{l}\text { Other cellulitis } \\
\text { Miscellaneous skin infections }\end{array}$ & 33 & 312 & $(190-481)$ & 34 & 271 & $(166-416)$ \\
\hline $\begin{array}{l}\text { Miscellaneous skin infections } \\
\text { Contact dermatitis }\end{array}$ & 12 & 503 & $(207-1013)$ & 10 & 380 & $(141-812)$ \\
\hline $\begin{array}{l}\text { Contact dermatitis } \\
\text { Pruritus }\end{array}$ & 32 & 160 & $(97-249)$ & 34 & 144 & $(88-220)$ \\
\hline $\begin{array}{l}\text { Pruritus } \\
\text { Corns }\end{array}$ & 9 & 142 & $(50-31$ & 18 & 162 & $(80-288)$ \\
\hline $\begin{array}{l}\text { Corns } \\
\text { Chronic ulcer of skin }\end{array}$ & 14 & 755 & $(336-1$ & 7 & 249 & $(72-609)$ \\
\hline $\begin{array}{l}\text { Chronic ulcer of skin } \\
\text { Other diseases of skin }\end{array}$ & 23 & 614 & $(334-1027)$ & 23 & 345 & $(188-578)$ \\
\hline Other diseases of skin & 16 & 230 & $(109-423)$ & 18 & 154 & $(77-275)$ \\
\hline CHAPTER XIII Diseases of the musculoskeletal s & system & & & & & \\
\hline Rheumatoid arthritis & 12 & 191 & $(79-384)$ & 11 & 70 & $(27-145)$ \\
\hline Osteoarthritis & 52 & 146 & $(99-207)$ & 97 & 121 & $(92-156)$ \\
\hline Non-specific arthritis & 18 & 136 & $(67-242)$ & 35 & 182 & $(112-277)$ \\
\hline Shoulder syndrome & 14 & 148 & $(66-28$ & 19 & 161 & $(82-282)$ \\
\hline Other bursitis, etc & 15 & 113 & $(52-212)$ & 12 & 105 & $(43-210)$ \\
\hline Other non-articular rheumatic disorders & 19 & 132 & $(67-232)$ & 23 & 125 & $(68-210)$ \\
\hline Non-specific limb pain & 30 & 179 & $(106-281)$ & 45 & 186 & $(122-270)$ \\
\hline Low back pain & 44 & 138 & $(90-201)$ & 43 & 117 & $(76-171)$ \\
\hline Osteoarthritis of spine & 10 & 153 & $(53-32$ & 19 & 177 & $(90-310)$ \\
\hline Cervical spine problem & 13 & 98 & $(42-192)$ & 17 & 96 & $(46-173)$ \\
\hline Intervertebral disc syndrome & 25 & 173 & $(97-284)$ & 19 & 138 & $(70-242)$ \\
\hline Other back pain & 7 & 163 & $(48-400)$ & 12 & 209 & $(86-420)$ \\
\hline CHAPTER XVI Symptoms, signs and ill-defined & conditio & & & & & \\
\hline $\begin{array}{l}\text { Dizziness } \\
\text { Headache }\end{array}$ & 19 & 143 & $(73-252)$ & 39 & 160 & $(102-239)$ \\
\hline Le & 9 & 111 & $(39-247)$ & 17 & 114 & $(55-207)$ \\
\hline $\begin{array}{l}\text { Odema-localised or depend } \\
\text { Chest pain }\end{array}$ & 14 & 213 & $(95-$ & 28 & 141 & $(82-226)$ \\
\hline $\begin{array}{l}\text { Chest pain } \\
\text { Cough }\end{array}$ & 21 & 131 & & 19 & 13 & $(70-242)$ \\
\hline sea and/or vomiting & 18 & 111 & $(55-1$ & 33 & 162 & $(98-249)$ \\
\hline $\begin{array}{l}\text { Nausea and/or vomiting } \\
\text { Abdominal pain }\end{array}$ & 16 & 326 & $(154-601)$ & 23 & 231 & $(126-387)$ \\
\hline $\begin{array}{l}\text { Abdominal pain } \\
\text { Malaise NEC }\end{array}$ & 29 & 151 & $(89-2$ & 36 & 128 & $(80-195)$ \\
\hline $\begin{array}{l}\text { Malaise NEC } \\
\text { Rash NEC }\end{array}$ & 11 & 125 & $(49-259)$ & 30 & 148 & $(88-234)$ \\
\hline $\begin{array}{l}\text { Rash NEC } \\
\text { Signs symptoms NEC }\end{array}$ & 6 & 92 & $(24-240)$ & 16 & 166 & $(78-305)$ \\
\hline Signs, symptoms NEC & 17 & 230 & $(112-416)$ & 16 & 206 & $(97-380)$ \\
\hline CHAPTER XVII Accidents, injury, poisoning and & $d$ violenc & & & & & \\
\hline & 14 & 127 & $(57-244)$ & 11 & 88 & $(35-182)$ \\
\hline Abrasions & 10 & 248 & $(92-532)$ & 12 & 228 & $(94-459)$ \\
\hline Bruises and contusions & 20 & 134 & $(70-233)$ & 39 & 150 & $(95-224)$ \\
\hline Adverse effects of medication & 19 & 287 & (146-504) & 28 & 228 & $(132-364)$ \\
\hline
\end{tabular}

$\mathrm{CI}=99^{\circ}{ }^{\circ}$ confidence interval 
Many illnesses are self limiting and minor in nature. For these, detailed investigation is unwarranted and diagnosis often imprecise. Though this is a legitimate criticism of general practice based studies, it does not apply to the diagnosis of serious illnesses nor does it influence the results of this study, in which any bias in diagnostic quality is equal in index and control populations.

In using diabetes as an example of morbidity, we acknowledge the potential for some loss of information about insulin dependent diabetics, who sometimes receive care in hospital outpatient departments for other conditions when attending for review of diabetes. Nevertheless, most conditions so treated are brought back to the general practitioner, who is invariably responsible for any prescribed medication. An additional problem specific to diabetes concerns the two types of the disease, which may have differing aetiologies. ${ }^{4}$ The study included approximately $18 \%$ of patients who were aged under 44 but the age at diagnosis, which might have provided a proxy for estimating the number of type 1 diabetics, is not known. In spite of the aetiological differences between type 1 and type 2 diabetes, there is an inference from this study that the pattern of concurrent disease is similar in both. The large number of significant findings are unlikely to have occurred if referable only to a portion of the index cases. A study of disease concurrence allows for making only limited conclusions about cause and effect. The vast majority of the diabetics were diagnosed before the study began, as were patients with many of the concurrent diagnoses. Self limiting illnesses of short duration (such as virus disorders) can be assumed to have occurred in established diabetics.

The method involves calculating an expected number of cases from a control population after standardising for age. By excluding persons present for only part of the study year, we have minimised the risk of underestimating prevalence in the control population (and therefore of overestimating relative prevalence in the index population), which might be attributed to inflation of practice patient registers. Another possibility of overestimating relative prevalence in index cases arises from the need for diabetics to consult more frequently (because of the danger of destabilising the diabetes), and once the person consults he may be more likely to report a secondary problem - a general practice equivalent of the Berkson bias. The extent of this bias is difficult to quantify since it can only be estimated in those morbidity rubrics for which we could be convinced from independent evidence that there is no association (positive or negative). Nevertheless, there were 153 male and 95 female diabetics who did not consult for any other condition during the year.

Set against these causes of overestimating relative prevalence in index cases, the control population inevitably includes all undiagnosed diabetics whose concurrent illnesses will inflate the prevalence in controls and potentially underestimate the relative prevalence in index cases. In this study we observed a diabetic person consulting rate of 7 per 1000 over the 12 month period, which is compatible with other contemporary studies, ${ }^{5}$ though some would argue that there are at least as many people in the community with undetected diabetes and many more with impaired glucose tolerance. ${ }^{6}$

The main analysis reported in this study is based on 160 comparisons ( 80 morbidity rubrics in each sex). With multiple testing of this number and using the $99 \%$ confidence interval, we might expect one or two to be significantly higher or lower by chance if there were no real differences. For 62 of them ( 34 male and 28 female), the lower limit of the confidence interval exceeded 100 and there was no example of the upper limit below 100 .

The study has shown associations between several infectious disorders and diabetes, providing a response to the comments of Tofte and Sabath that "although it is a frequently stated clinical axiom that diabetics are more susceptible to bacterial and fungal infections than non diabetics of similar age/sex and social economic backgrounds, there is a paucity of supporting evidence in the literature". ${ }^{7}$ Mumps and rubella and some other viruses have been incriminated as aetiological factors for diabetes, ${ }^{8}$ but the associations described here are concerned with virus disorders in existing diabetics. Vaginal thrush is widely recognised as a presenting symptom of diabetes and the strong associations between diabetes and fungal infections shown here are hardly surprising. In this study, the increased prevalence of skin infections suggests an increased susceptibility for diabetics to bacterial infection, though other published evidence is not so conclusive. ${ }^{9}$

The results for neoplasms provide a contrast to those for all other chapters in the disease classification. Pancreatic carcinoma and diabetes has been studied, ${ }^{10}$ but otherwise the relationship between malignancy and diabetes is not well documented. This one year general practice based study involving nearly 2000 diabetics clearly has not the statistical power to detect associations of uncommonly occurring individual malignancies.

The concurrence of diabetes and hypothryroidism confirms widely held clinical opinion. There is good evidence of association between diabetes type 1 and the presence of thyroid autoantibodies and also gastric parietal cell autoantibodies, ${ }^{11}$ and further supportive evidence of association with biochemical hypothyroidism. ${ }^{12}$ There is no evidence of any such association among type 2 diabetics. Our study, however, includes diabetics of both types and it is unlikely that there were sufficient type 1 cases to account for this association by themselves.

Blindness is a well known problem for diabetics. Diabetic retinopathy is responsible for $10 \%$ of new cases of blindness, and diabetes is the leading cause of blindness in middle age. ${ }^{13}$ Neovascular glaucoma is a particular complication of diabetic retinopathy, and chronic simple glaucoma and cataracts are more frequent in patients with diabetes. ${ }^{13}$ The findings in this study are consistent with these observations.

The associations between diabetes and cardiovascular disease are the best documented and, in their total impact on the diabetic, the most serious. The nature of the association is uncertain 
but there are predisposing risk factors common to diabetes and to cardiovascular disease generally. The findings of the study largely conform to other data. ${ }^{35}$ The standardised person consulting ratios for myocardial infarction, and similar values for other ischaemic heart disease, accord with the observation that the risk of cardiovascular death in diabetics is at least twice that of non-diabetics. ${ }^{5}$ The greater values of standardised person consulting ratios for females than for males (due to the reduced expected values in female controls) also accord with other data. ${ }^{3}$

Increased severity of periodontal disease amongst diabetics has been reported. ${ }^{14}$ Standardised person consulting ratios for disorders of the teeth, though increased at the $5^{\circ}$ o level, did not achieve the $1 \%$ level used throughout this paper.

Emphysematous cholecystitits is a particular complication of cholecystitis in diabetics. ${ }^{15}$ In this study, there were 12 females compared with five expected (SPCR $254,99 \%$ CI 105-511) who were reported as having gall bladder disease.

Urinary tract infections and haematuria were both more likely in diabetics. A higher incidence of urinary tract infection in females though often asymptomatic has been reported before. ${ }^{16}$

This analysis of disease concurrence illustrated by diabetes has shown the usefulness of data gathered routinely in a general practice based morbidity study. It has provided, in a large cohort of diabetics, considerable support for widely held opinions about diabetes and in general accords with the findings of other epidemiological studies. In addition, areas of disease have been identified in which there are no materially relevant associations, including cancer and disorders in which allergy plays an important part. This morbidity study, which was concerned with nearly 300000 persons, provides opportunities to examine data relevant to other index diseases.

The most appropriate acknowledgement in all studies involving several general practices is to all those involved in the considerable exercise of data capture, including both the general practitioners and the practice ancillary staff. In the preparation of this paper we are pleased to acknowledge the assistance of the Office of Population Censuses and Surveys, in particular the staff involved in the extensive programming exercises required. In addition, the observations of Dr Anna McCormick of the OPCS have been particularly helpful in both the design and execution of this study.

1 Birmingham Research Unit of the Royal College of General Practitioners. "The Diagnostic Index" $\mathcal{f}$ Roy Coll Gen Pract 1971; 21: 609-12.

2 Royal College of General Practitioners, Office of Population Censuses and Surveys, Department of Health and Social Security. Morbidity statistics from general practice-Third national study 1981-1982. A publication of the Government Statistical Service. Series MB5 No 1. London: HMSO, 1986.

3 US Dept of Health Education and Welfare. Diabetes data: compiled 1977. Publication No (NIH) 78-1468. Washington, DC: US Government Printing Office, 1978.

4 Irvine WJ. Classification of idiopathic diabetes. Lancet 1977;

5 West KM. Epidemiology of diabetes and its vascular lesions.

New York: Elsevier North Holland, 1978 .
College of General Practitioners. A diabetes survey. Report of a working party. $\mathrm{Br} M$ Med $\mathcal{f} 1962$; i: 1497-503.

7 Tofte RW, Sabath LD. Infection in patients with diabetes mellitus or obesity. In: Brodoff BN, Bleicher SJ, eds. Diabetes mellitus and obesity. Baltimore: Williams and Wilkins, 1982

8 Craighead JE. The role of viruses in the pathogenesis of pancreatic disease and diabetes mellitus. Prog Med Virol 1975; 19: 161-214.

9 Keene WR, Minchew BH, Cluff LE. Studies of the epidemiology of staphylococcal infection. III. Clinical factors in susceptibility to disease. N Engl f Med 1961; 265 1128-34.

10 Karmody AJ, Kyle J. The association between carcinoma of the pancreas and diabetes mellitus. $B r \mathcal{F}$ Surg 1969; 56 $362-4$.

11 Irvine WJ, Clarke BF, Scarth L, Cullen DR, Duncan LJP. Thyroid and gastric autoimmunity in patients with diabetes mellitus. Lancet 1970; ii: 163-8.

12 Gray RS, Irvine WJ, Toft DA, Seth J, Cameron EHD, Clarke BF. Unrecognised thyroid failure in diabetes mellitus. F Clin Lab Immunol 1979; 2: 221-4.

13 Bresnick GH. Ocular complications of diabetes mellitus. In: Brodoff BN, Bleicher SJ, eds. Diabetes mellitus and obesity. Baltimore: Williams and Wilkins, 1982.

14 Belting CM, Hiniker JJ, Dummett CO. Influence of diabetes mellitus on the severity of periodontal disease. $\mathcal{F}$ Periodontol 1964; 35: 476-80.

15 Scaparello JHB, Sladen GE. Progress report: diabetes and the gut. Gut 1978; 19: 1153-62.

16 Vejsgaard $R$. Studies in urinary tract infections in diabetes. I. Bacteriuria in patients with diabetes mellitus and in control subjects. Acta Med Scand 1966; 179: 173-82. 